\title{
Variability in beech : budding, height growth and tree form
}

\author{
E. TEISSIER DU CROS ${ }^{*}$, B. THIEBAUT ${ }^{* *}$ \\ with the technical cooperation of H. DUVAL * \\ * INRA, Station d'Amélioration des Arbres forestiers, \\ Centre de Recherches d'Orléans, Ardon, F 45760 Olivet \\ ** U.S.T.L., Institut de Botanique, 163, rue Auguste-Broussonnet, \\ F 34000 Montpellier \\ and \\ C.N.R.S., Centre Louis-Emberger, BP 5051, F 34033 Montpellier Cedex
}

\begin{abstract}
Résumé
Variabilité chez le hêtre : débourrement végétatif, croissance en hauteur et forme des plants
\end{abstract}

Le hêtre est planté en France en plein ou en complément de régénération. Le choix des meilleures sources de graines est basé sur l'établissement d'expériences comparatives multistationnelles de provenances. Un tel réseau de dispositifs a débuté en 1976 avec 39 provenances françaises (tabl. 1 et 2, fig. 3).

Les trois caractères observés ont tous un impact économique.

Un débourrement végétatif tardif est recherché pour les plantations en plein découvert à basse altitude dans des sites sensibles aux gelées printannières. Ce caractère est sous fort contrôle génétique, il est stable dans le temps (fig. 4) et dans l'espace (fig. 5). De plus, il semble soumis à une légère loi de variation. Des provenances d'altitude élevée ont, à basse altitude, un débourrement plus precoce que des peuplements de basse altitude. Cette règle n'est pas absolue (fig. 6), mais les observations réalisées dans les expériences comparatives de provenance ont permis de déterminer des peuplements à débourrement tardif.

La vigueur, diagnostiquée ici par la croissance en hauteur, est aussi un caractère variable (tabl. 3). Son déterminisme génétique n'est pas très puissant chez le hêtre et elle est soumise à une forte interaction génotype-environnement. Sauf exception, il est donc difficile de trouver des provenances vigoureuses « passe-partout». Par contre, dans un milieu donné, la différence de croissance entre la provenance la plus vigoureuse et la provenance la moins vigoureuse atteint dès le jeune âge l'équivalent d'une année de croissance. Une provenance vigoureuse a donc besoin de moins de dégagements qu'une provenance moins vigoureuse. Croissance en hauteur et débourrement végétatif sont deux caractères indépendants (tabl. 6).

La fourchaison du hêtre est un défaut que le forestier aimerait corriger. Elle a été mesurée sur de jeunes hêtres soit en comptant le nombre de rameaux concurrençant la tige principale (fourches), soit en mesurant l'incidence du polycyclisme sur la croissance annuelle, caractère dont on sait qu'il peut conduire à la fourchaison. Dans certains sites expérimentaux la fourchaison, surtout lorsqu'elle est appréciée par l'incidence du polycyclisme (fig. 1 et 2), est un caractère variable. Mais elle est aussi très dépendante du milieu (pluviosité, par exemple). Il en résulte une forte intéraction génotype-environnement. La fourchaison semble diminuer avec l'âge (tabl. 4 et 5 ) et on sait que des plantations denses réduisent aussi le risque de fourchaison. Ces facteurs conduisent tous les deux à une augmentation de la concurrence entre plants, ce qui rejoint l'hypothèse faite par divers auteurs selon laquelle trop d'abondance pour le hêtre (lumière, espace, eau, fertilité) peut conduire à un fort polycyclisme qui, s'il concerne aussi les rameaux latéraux, 
peut se traduire par des fourches. La conduite des peuplements plantés est donc très délicate, mais doit certainement commencer par une densité de plantation relativement supérieure à celle qui est préconisée actuellement en France. Le choix de provenances à la fois vigoureuses et peu enclines à fourcher est difficile, mais néanmoins faisable, essai par essai. Les provenances suivantes ont un débourrement végétatif tardif et sont au-dessus de la moyenne pour la vigueur et la forme : Chatillon, Compiègne, Sousceyrac et Perche-Trappe.

Mots clés : Fagus sylvatica, provenance, variabilité, phénologie, croissance, forme.

\section{Summary}

Three types of characteristics of beech with an economic impact, i.e. flushing, height growth and forking, have been studied in 7 provenance tests laid out in 5 different French locations. Bud burst is under strong genetic control. Therefore the choice of late flushing provenances which will resist late spring frosts is possible. Height growth and forking are also genetically controlled but to a lesser extent. Site effect is high and results in a strong genotype-site interaction. Therefore, the choice of provenances with a high vigour and without forks, two genetically independant characteristics, will need careful observation in regional provenance tests. A few such provenances are proposed.

Key words : Fagus sylvatica, provenance, variability, phenology, height growth, tree form.

\section{1. introduction}

French studies on beech variability were initiated in 1976 with the lay-out of a multisite series of provenance tests. First results concerned soil-provenance interaction (Lepoutre \& Teissier du Cros, 1979 ; Teissier du Cros \& Lepoutre, 1983), and form and architecture of young beech trees in connection with polycyclism and shoot growth (Dupre et al., 1984, 1985, 1986). Allozyme electrophoretic analysis has also been used to describe genetic variation in beech within its range and more specifically in the Mediterranean region (Thiebaut, 1984 ; Barrière et al., 1985 ; Cuguen et al., 1985). Finally, work on the spiral grain of mature trees was published in cooperation with a German team (Azoeuf et al., 1980).

Since planting, a series of observations have been made in 7 provenance tests (table 1). They concerned bud burst, height increment and tree form. Two factors were to be studied : genetic variability and effect of plant age.

\section{Materials and methods}

\subsection{Provenance trials}

Trial sites (table 1 and fig. 3) were chosen either because they are in regions where reafforestation with beech occurs currently (Ecouves, Sommedieue, Montagne Noire) or because they belong to a region where beech would have a great potential (western slopes of Massif Central : Chaud), or because they were at hand for a concentrated series of observations (Orléans). 


\subsection{Provenances}

They were sampled in French beech stands which had been either selected for seed production or were unselected (table 2). These stands represent most types of site conditions where beech occurs naturally (fig. 3 ).

\subsection{Designs}

The Orléans 11 trial, having the largest number of provenances, was used as a reference for the estimation of provenance-site interaction. All trials consisted of complete replications of all the provenances they included (table 1). The main characteristics and the location of the 7 provenance trials are given in table 1 and figure 3 . Trials 1 to 6 were sown in the same nursery of INRA, Nancy, and during the same period.

\subsection{Observations}

They varied according to trials, but they generally included :

- Total height at different ages.

- Stem diameter $5 \mathrm{~cm}$ above ground level.

- Number of branches competing with the terminal shoot leading to forks, observed with the empirical "forester's eye ".

- Number of forks, connected to growth patterns defined in previous papers (monopodial + sympodial forked shoot growth), considered as an explanatory observation of forking habit (Thiebaut et al., 1985 ; DUPRE et al., 1986).

- Ratio of orthotropic growth (Lammas shoots) on total shoot growth (plagiotropic + orthotropic) (fig. 1 and 2). One must remember that polycyclism may result in forking when concerning lateral shoots or when taking place too late during the growing season (LE TACON, 1983). Consequently, forking has been approached in two ways : a probabilistic approach and an architectural approach.

- Budding in spring in connection with susceptibility to late frosts. Budding was observed by two techniques. In Orléans, trees were considered to have flushed, the day when their terminal bud had reached a particular phenologic stage i.e. the beginning of elongation. Each year, surveys started at the end of April. The first survey was made on a day when no terminal bud had yet reached that phenologic stage, for instance Monday April 25th. Three surveys a week were scheduled until all trees had flushed (usually one month later). Therefore, a tree having flushed on Wednesday May 4th was given the value 9 days and a tree having flushed on Friday 13th received the value 18 days (fig. 4, abscissae in fig. 5 and ordinates of fig. 6). When such frequent observations were impossible, as in Eawy (the nursery in which Ecouves seedling were raised) the terminal bud of each seedling was observed once with a scale ranging from 1 referring to a dormant bud, to 7 for a bud whose leaves were developed with a beginning of stem elongation (ordinates of fig. 5). Tests on these variables (number of days, scale) showed that they could both could be considered statistically normal. 


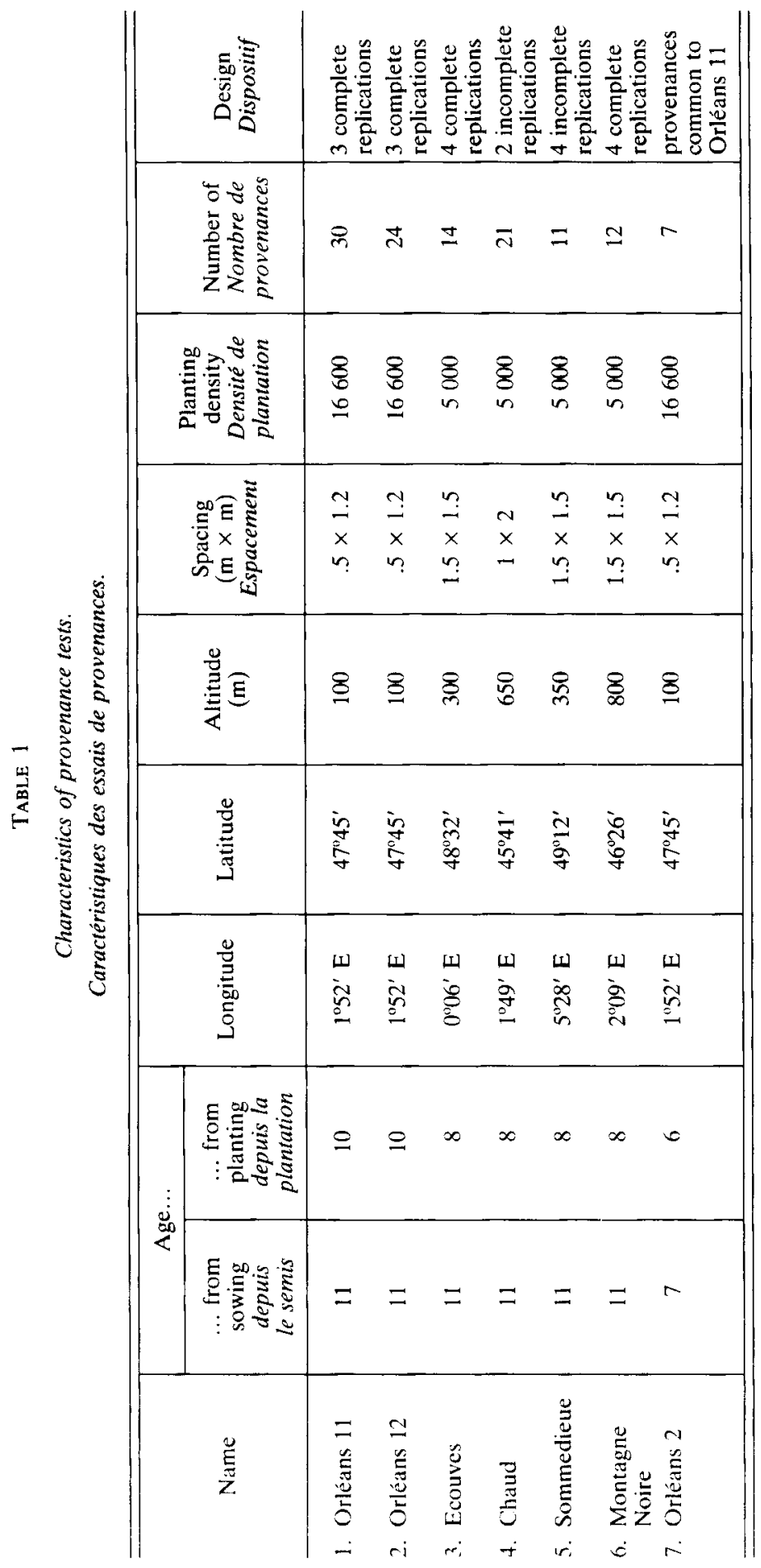




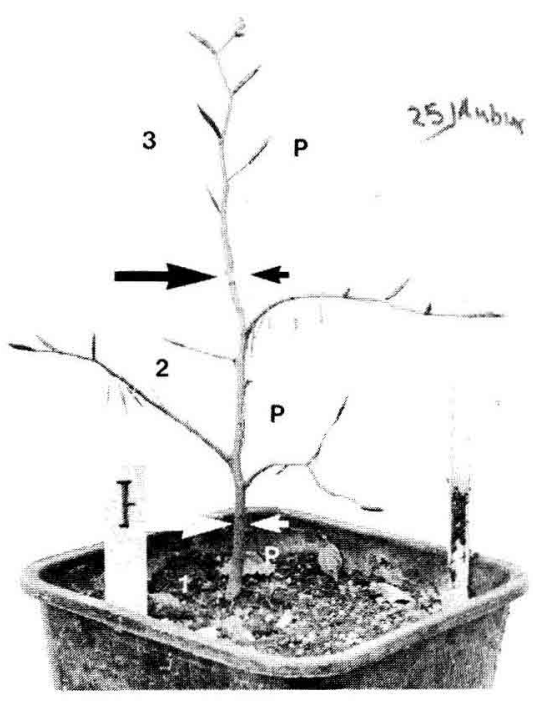

A

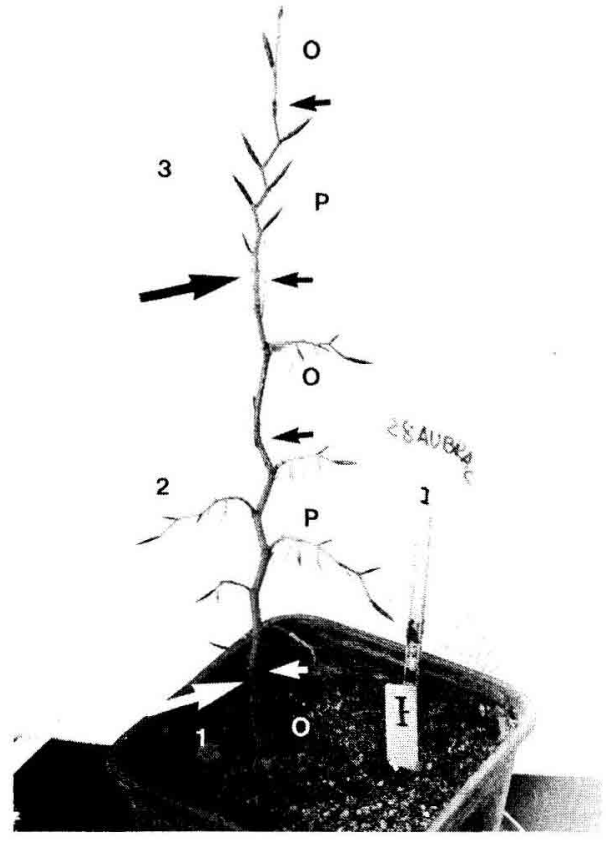

C

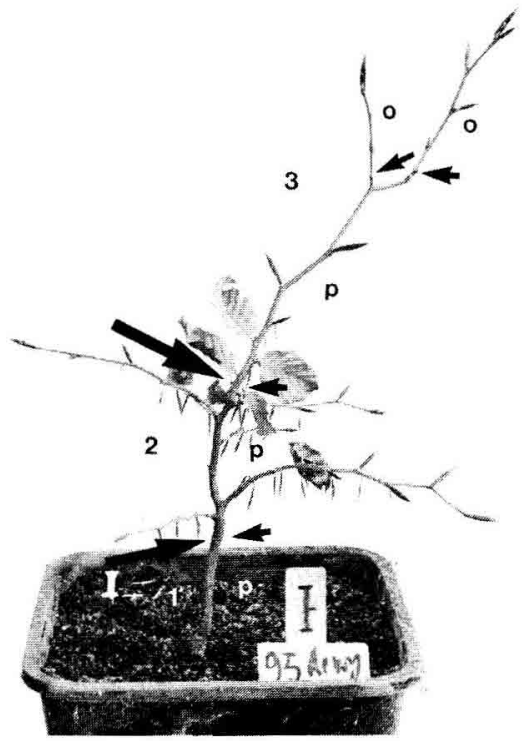

B.

FiG. 1

Polymorphism in three-year-old seedlings without (1-A) or with (1-B and I-C) polycyclism. Photo taken in October.

Polymorphisme chez des semis de hêtre de 3 ans, en octobre, sans (I-A) et avec $(I-B$ et $I-C)$ polycyclisme.

- : Limit between shoots (1,2 and 3). Limite des pousses (1, 2 et 3 ).

$\leftarrow$ : Limit between cycles ( $\mathrm{P}$ or $\mathrm{O}$ ). Limite des cycles ( $P$ ou $O)$.

$\mathrm{P} \quad$ : Plagiotropic cycle (first growth cycle after age 1).

Cycle plagiotrope (premier cycle à partir de 2 ans).

O : Orthotropic cycle (first year and second growth cycle after age 1).

Cycle orthotrope (première année et deuxième cycles ou plus, à partir de 2 ans).

When concerning lateral buds, polycyclism may result in a fork (1-B).

S'il concerne des bourgeons latéraux, le polycyclisme peui se traduire par une fourche $(I-B)$. 

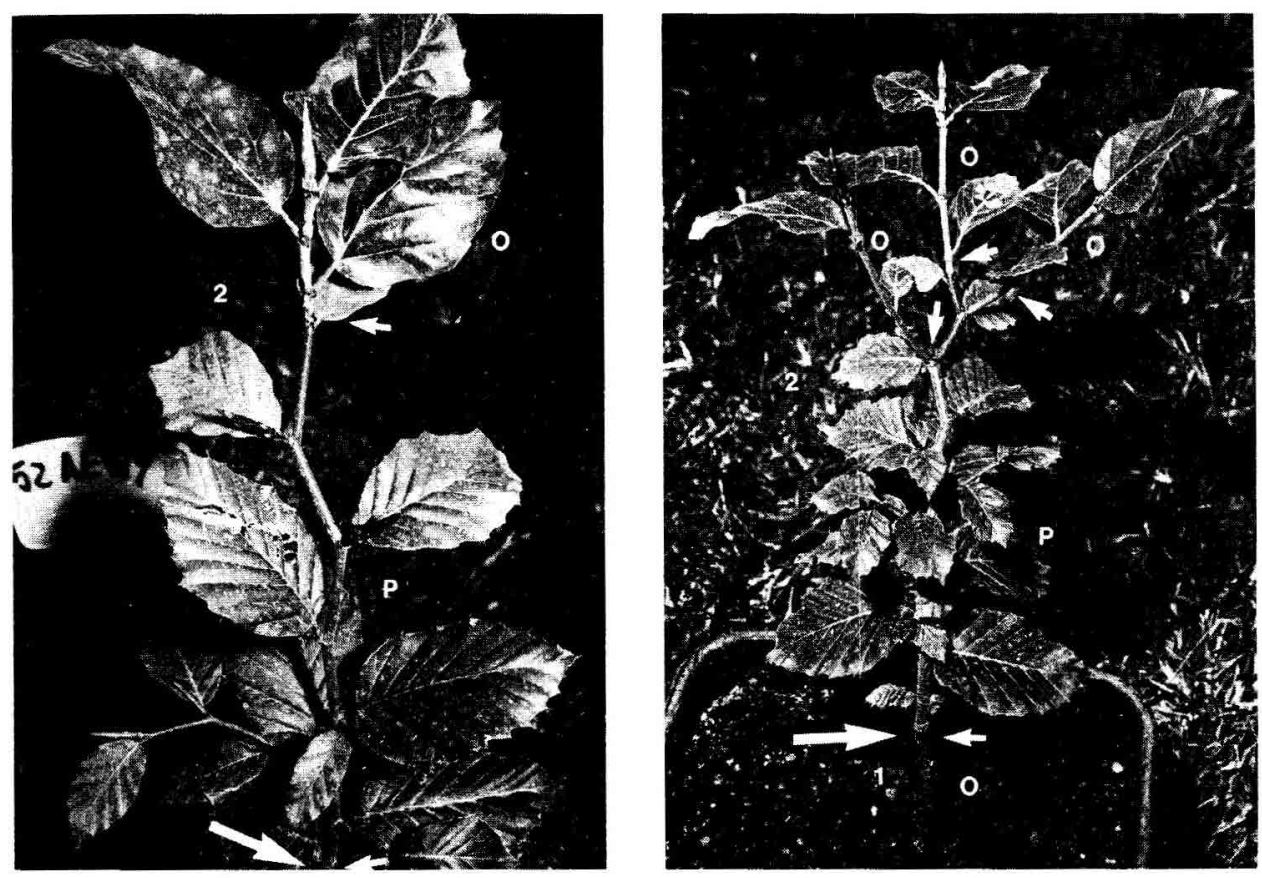

网

B

FIG. 2

Polymorphism in leaves and stems of 2-year-old beech seedlings (photo taken in September).

Polymorphisme des feuilles et des tiges en septembre chez des semis de hêtre de deux ans.

When concerning the terminal shoot only (2-A) polycyclism is an advantage. But when concerning lateral buds also (2-B) polycyclism may result in forking.

$S$ 'il concerne la pousse terminale seulement (2-A) le polycyclism est avantageux. Mais s'il concerne aussi des bourgeons latéraux (2-B) il peut se traduire par des fourches.

- Evolution of traits with time. Two methods were used :

- measuring the same experiment at different periods. In this case the trees are exactly the same apart from age, but environmental conditions vary steadily with tree height growth and crown expansion. Environmental conditions may also vary unpredictably because of temperature and rainfall. All trials except Sommedieue and Montagne Noire were measured during the winter 1983-1984 and again two years later ;

- measuring two experiments of different age, with common provenances, at the same site. In this case apart from age and concomitant plant height and crown diameter, site conditions (soil, climate) are exactly the same. Simultaneous observations of 7 provenances common to trials Orléans 11 and Orléans 2 were made. 


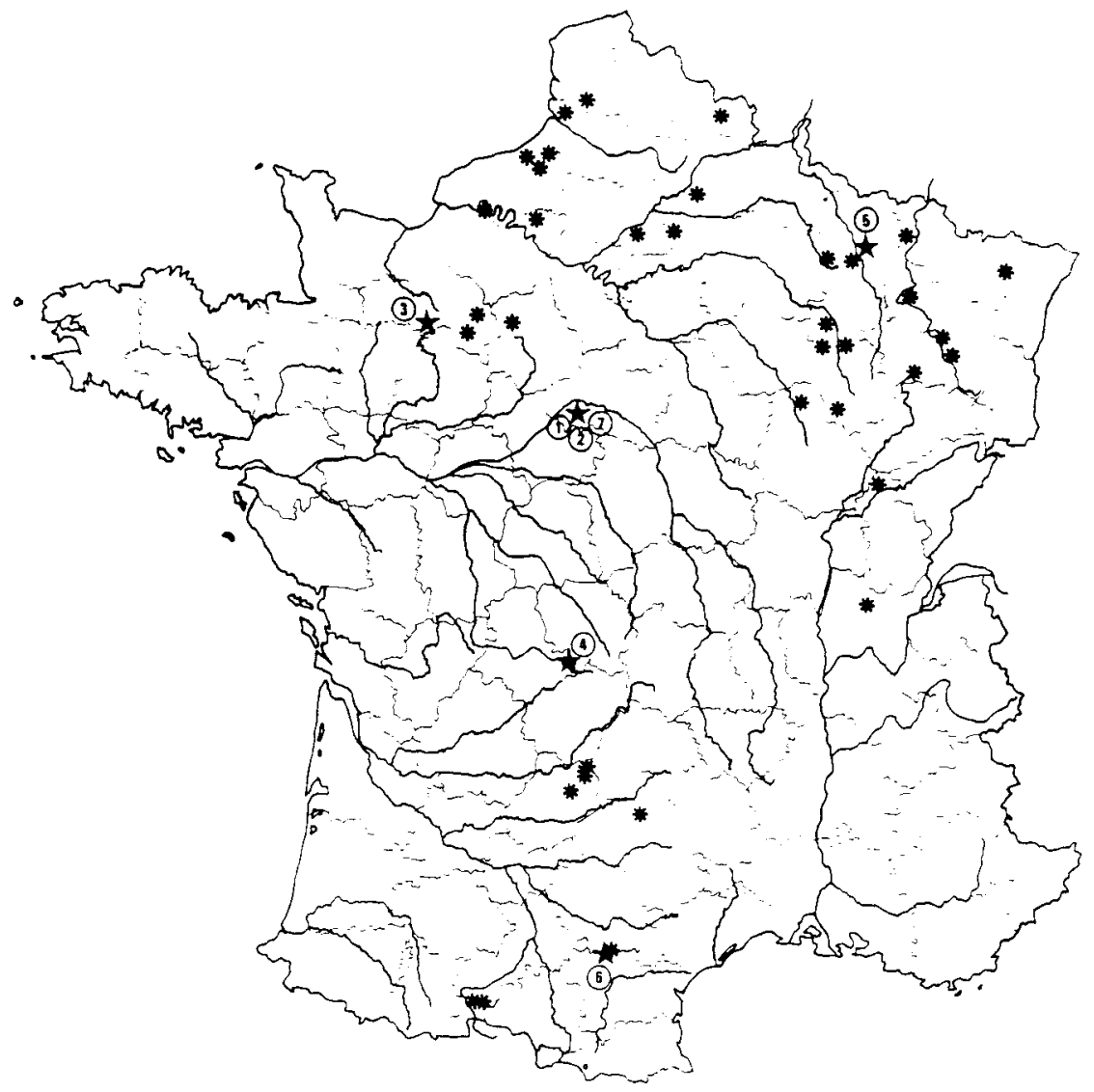

FI(i. 3

* Location of provenances.

Localisation des provenances.

* Location of provenance trials.

Localisation des essais de provenances.

(1) Trial number in table 1 .

Numéro des essais an tableau 1 .

\section{Results}

\subsection{Trait variability (table 3 )}

Generally, most traits observed varied between provenances. Exceptions occur when the provenance-replication interaction becomes significant.

Budding is always a very variable trait. At Orléans 11 , the difference between the earliest and the latest provenance is 10 days. Budding ranking shows stability when observed in different years (fig. 4), and at different locations (fig. 5). Finally there is a slight tendency in late flushing provenances to originate from lower elevations than early flushing ones (fig. 6). 
TABLE 2

Origin of the provenances and total height in 1985 according to the trials. Coordonnées des provenances et hauteur totale en 1985 selon les essais.

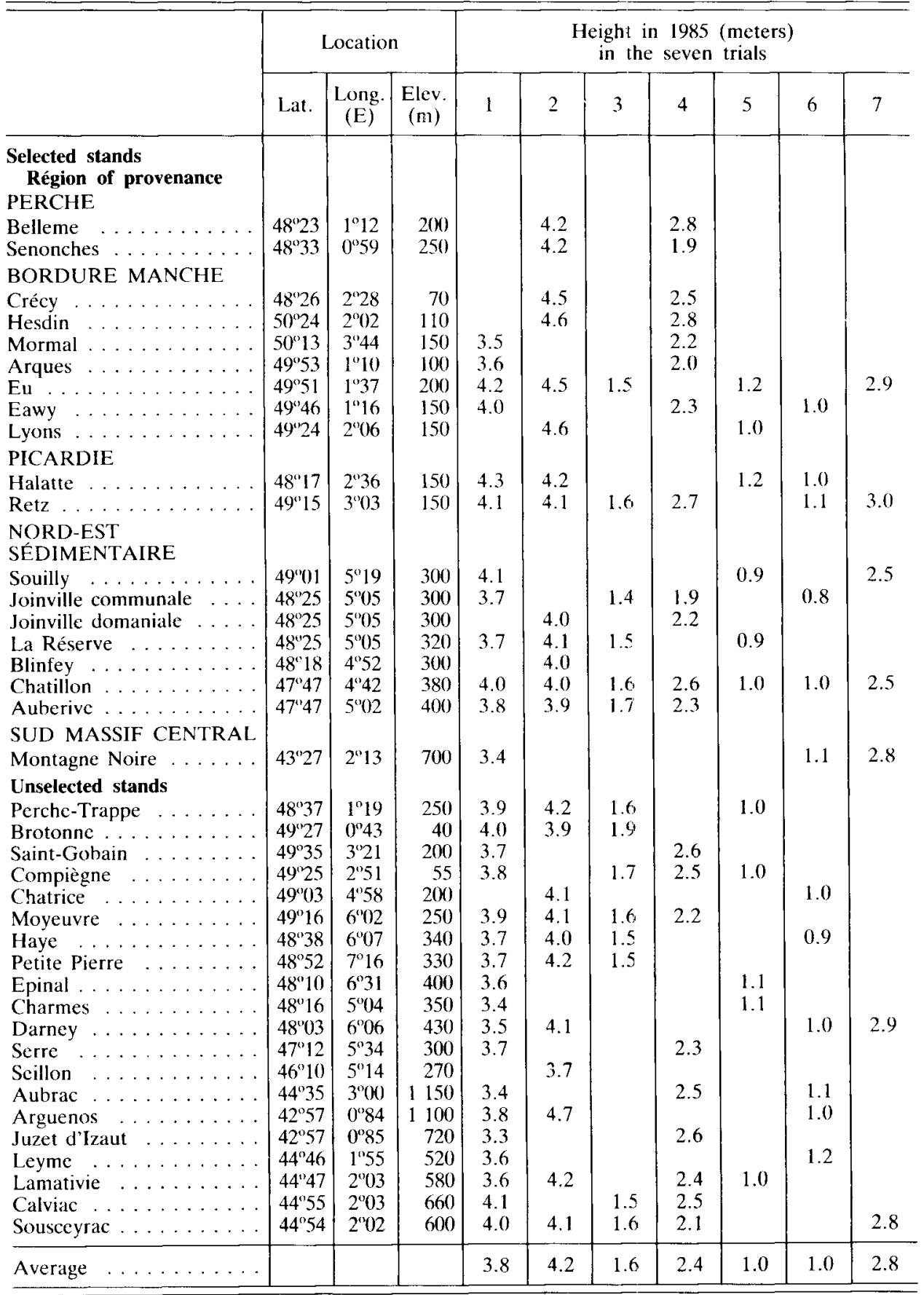


VARIABILITÉ DU HÊTRE

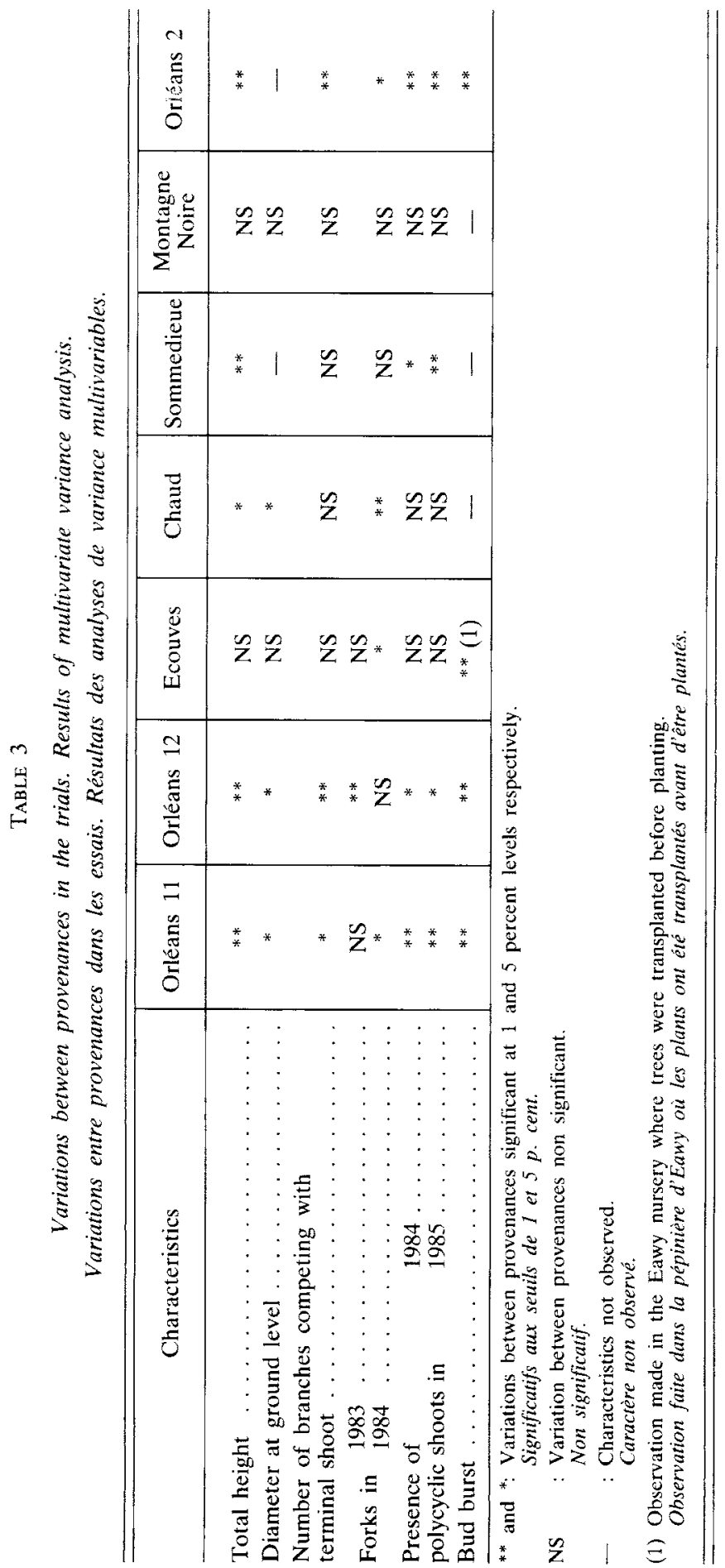




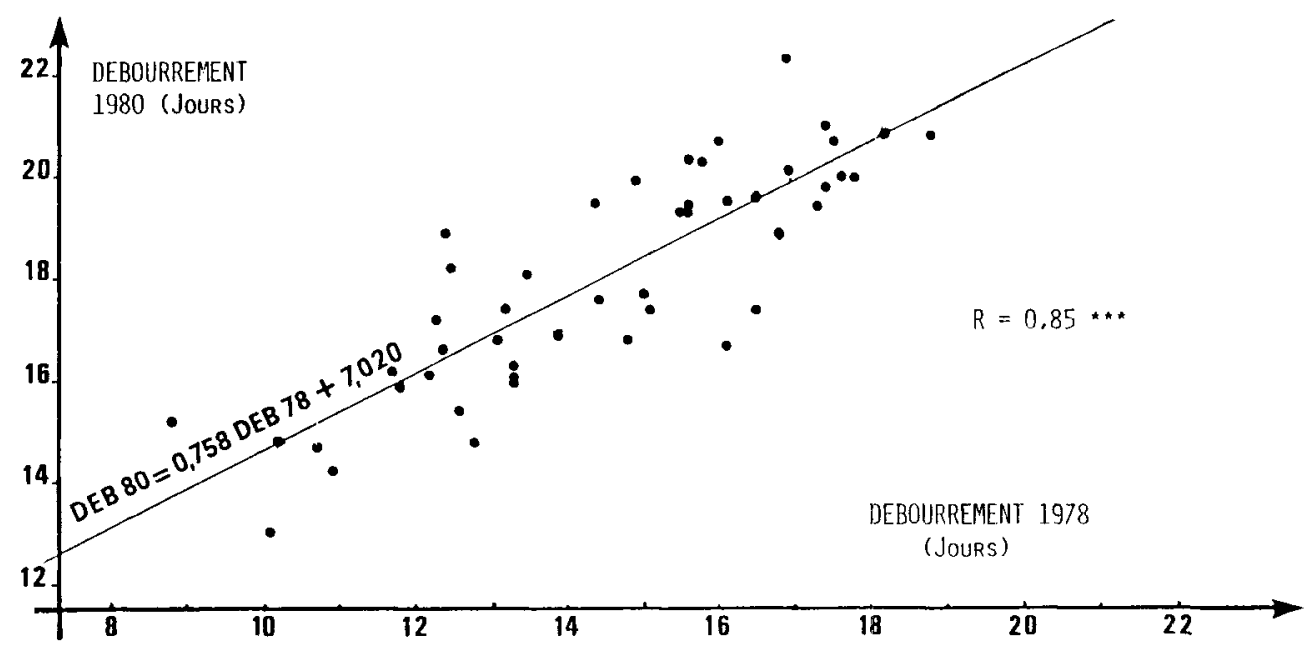

Fig. 4

Year effect on budburst (débourrement $=$ budburst $;$ jours $=$ days ; *** correlation coefficient significant at 1 per thousand level).

Stabilité du débourrement dans le temps, ${ }^{* * *}$ coefficient de corrélation significatif à 1 pour mille.

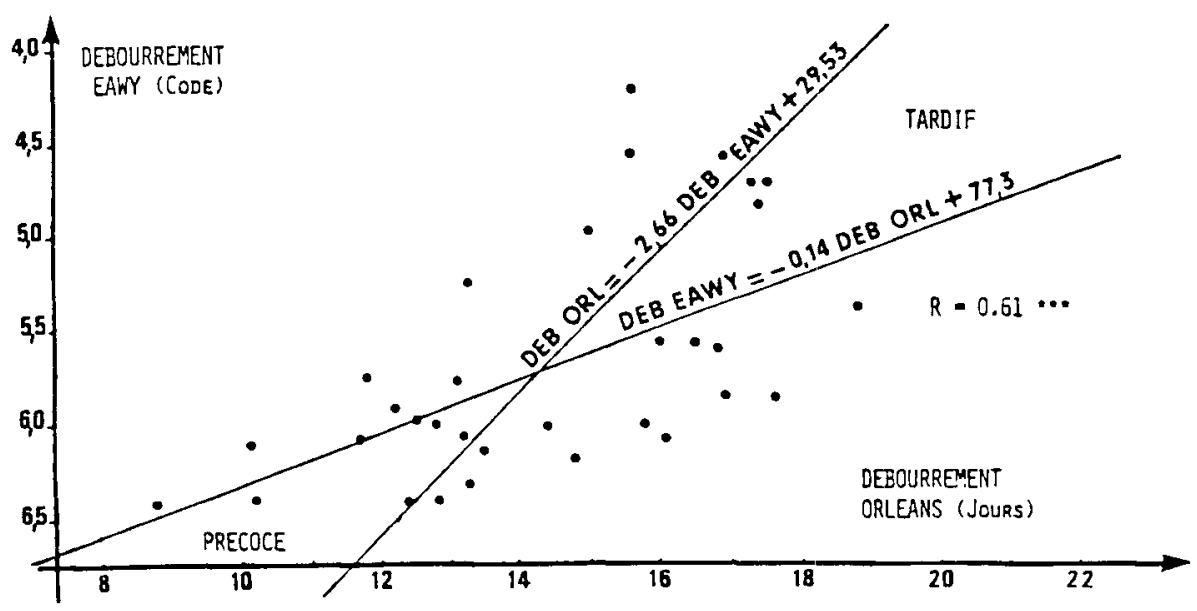

Fig. 5

Site effect on budburst (débourrement $=$ budburst ; précoce $=$ early ; tardif $=$ late ; Eawy and Orléans are two nurseries where provenances were tested, ${ }^{* * *}$ correlation coefficient significant at 1 per thousand level).

Stabilité du débourrement de l'espèce; Eawy et Orléans, deux pépinières où les provenances ont été comparées; ${ }^{* * *}$ coefficient de corrélation significatif au seuil de 1 pour mille. 
TABLE 4

Age effect on forking.

Effet de l'âge sur la fourchaison.

\begin{tabular}{c|c|c|c|c|c}
\hline \multicolumn{1}{c|}{$\begin{array}{c}\text { Provenance } \\
\text { tests }\end{array}$} & Orléans 11 & Orléans 12 & Ecouves & Chaud & Orléans 2 \\
\hline Forks * in 1983 .. & 1.16 & 1.36 & 1.05 & 0.80 & 0.90 \\
Forks in 1985 . . & 1.00 & 1.16 & 0.89 & 0.72 & 0.80 \\
\hline
\end{tabular}

$\left(^{*}\right)$ Mcan number of forks per tree and per year since planting.

\section{TABLE 5}

Evolution of forking and polycyclism with age (mean of 7 provenances common to 2 trials of different age in the same site).

Evolution de la fourchaison et du polycyclisme avec l'age (moyenne de 7 provenances communes à deux essais d'âge différent dans le même site).

\begin{tabular}{|c|c|c|c|}
\hline Provenance test & Orléans 11 & Orléans 2 & $\begin{array}{c}\text { Level of significance } \\
\text { of variance } \\
\text { analysis (3) }\end{array}$ \\
\hline Age (yrs) & 11 & 8 & \\
\hline Forking (1) (fourchaison) & 0.15 & 0.18 & NS \\
\hline Polycyclism in shoots (2) 1984 & 0.34 & 0.50 & $* *$ \\
\hline 1985 & 0.40 & 0.62 & $* *$ \\
\hline
\end{tabular}

(1) Ratio : number of trecs with monopodial or sympodial forks appearing on 1984 terminal shoot over total number of trees in a plot.

Rapport: nombre d'arbres avec des fourches monopodiques ou sympodiques apparues en 1984 sur le nombre total d'arbres de la parcelle unitaire.

(2) Percentage of orthotropic growth over total year growth.

Pourcentage de croissance orthotrope sur la pousse totale de l'année.

(3) NS : not significant; ${ }^{* *}$ : significant at 1 p. cent level.

NS: non significatif; ;* : significatif au seuil d'un pour cent.

Height (table 2) and diameter growth variation between provenances is more important in favourable sites than in harsh sites. As an illustration, total height at age 11 is $2.4 \mathrm{~m}$ in Chaud, a rich site with high rainfall, and $3.8 \mathrm{~m}$ in Orléans 11 , where trees were grown in nursery conditions with fertilisation and irrigation. In contrast height at age 11 is only $1.6 \mathrm{~m}$ in Ecouves, with a poor and shallow soil, and $1.0 \mathrm{~m}$ in Montagne Noire, a site stressed by drought and wind in summer and by snow in winter.

Tree architecture varies between provenances at several sites. When forking is assessed with the "forester's eye", variation only appears at Orléans. Elsewhere, variation is always hidden by a change of provenance ranking between replications (interaction). However, when the growth pattern is considered in forking assessment, using explanatory observations, a difference between provenances also appears in trials like Ecouves and Chaud in 1984. 


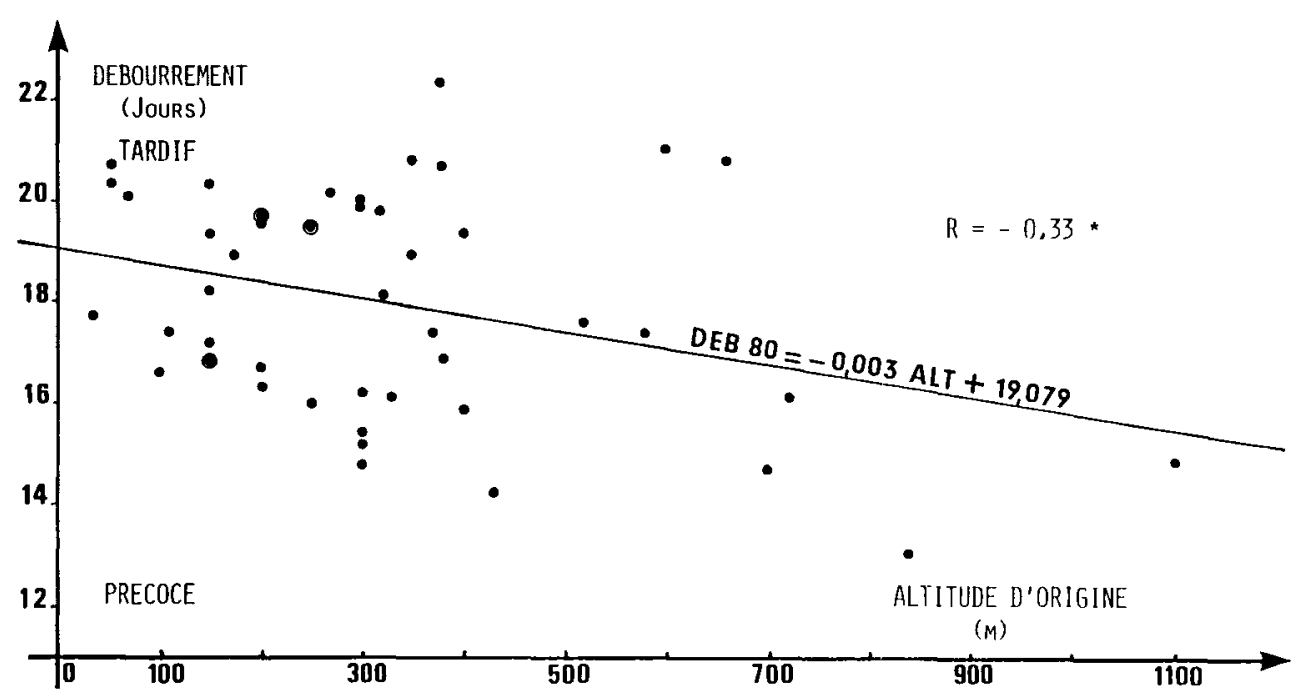

Fig. 6

Effect of stand elevation on budburst in a comparative test (débourrement $=$ budburst $;$ jours $=$ days ; tardif $=$ late $;$ précoce $=$ early). ${ }^{*}$ corrélation coefficient significant at 5 p. cent level.

Effet de l'altitude sur le débourrement dans un test comparatif;

* coefficient de corrélation significatif au seuil de $5 \%$.

\subsection{Trait evolution with time}

- Observation of the same experiments at a 2-year interval.

Table 4 shows a slight but steady decrease in forking with age. Although a 2-year interval might be considered short to arrive at a conclusion, a simultaneous decrease in forking in five different trials and on three different sites is observed.

- Observation of seven provenances common to 2 trials of different ages.

The comparison of seven provenances common to Orléans 11 (age 11) and Orléans 2 (age 8), in table 5, shows a slight although not significant reduction in forking and a strong decrease in the incidence of polycyclism on shoot growth with increasing age.

\section{Discussion}

\subsection{Consequence of the variability}

In all trials the height difference between the most vigorous and the weakest provenance is roughly equivalent to a one-year terminal shoot length. In the Orléans 11 trial, which has been measured every year since planting, it was observed that this same 
difference has been maintained from age 4 to age 11. Such a difference, although not significant when trees will be fully developed, is of great economic interest in young trees. A vigorous provenance will outgrow competing vegetation quicker than a weak one. Therefore it will be less expensive to keep this vegetation under control after planting.

Budding is also of great economic importance. In many regions, beech is planted without shelter and young plantations suffer from late frosts occuring after budding (TeIssier dU Cros, 1981). Meteorological observations made at a weather station near Orléans show that a 10-day delay in budding during a period ranging from late April to early May decreases frost risk by 50 percent. Moreover, as flushing is not correlated with height growth (table 6) the choice of late flushing provenances appears to have no relationship with the length of the growing season. Our observations confirm those of Galoux (1986) who found in progeny tests that the total genetic variance represents 93 percent of the variation. Therefore, as for many other forest tree species, late flushing provenances are needed for low elevation plantations. They can be found in different regions such as the northeastern part of the Seine river basin (elevation under 200 meters), in northeastern France (under $400 \mathrm{~m}$ ) and in the southwestern foothills of the Massif Central mountains (under $600 \mathrm{~m}$ ). Conversely, early flushing provenances are found in high elevation stands: Pyrénées, Southern Massif Central (over $500 \mathrm{~m}$ : Aubrac and Montagne Noire), in the Vosges foothills (around 300 to $400 \mathrm{~m}$ ) and also in northwestern France (below $150 \mathrm{~m}$ ). Unfortunately, no general rule can be given. The low phenotypic correlation between provenance elevation and bud burst originates partly from provenances in the same region or in the same stand which appear as late flushers or early flushers. As it is impossible to compare the flushing habit of different stands with in situ observations the only way to observe flushing ranking is in comparative tests. Another solution is of course to find methods to protect young trees from late frosts (lateral or overhead shelters), but this is in foresters' hands.

TABLE 6

Phenotypic correlations between total height (TH) and budburst (BB) of 30 provenances in 1981 and 1982 (trial Orléans 11).

Corrélation phénotypique entre la hauteur totale $(T H)$ et le débourrement végétatif $(B B)$ de 30 provenances en 1981 et 1982 dans l'essai Orléans 11.

\begin{tabular}{l|r|r|r}
\hline & TH81 & TH82 & BB81 \\
\hline TH82 & .951 & & \\
BB81 & -.036 & .062 & \\
BB82 & -.095 & -.029 & 0.884 \\
\hline
\end{tabular}

Fairly complete information has been already given in other papers about the morphology of young beech trees of our provenance tests in connection with the environment and the genetic variability (Dupre, et al., 1985 and 1986). Briefly, stem forking appears as a severe defect which originates mainly from the simultaneous polycyclic growth of terminal and lateral shoots of young beech trees. The variability between provenances is high but it is hidden by a strong genotype-site interaction. In the present report two sets of information have been given. 
Stem forking cannot be estimated accurately from the number of existing or potential forks alone. It is estimated more precisely when polycyclism is included in the observations. Therefore results obtained by the probabilistic approach and the architectural approach are complementary.

Stem forking seems to decrease when trees grow taller. The main factor which may be involved in forking decrease is the competition between trees. Competition acts in terms of space occupation and the interception of light and nutrients. Competition for space has been studied in Germany in a provenance-spacing trial (MUHLE \& KAPPICH, 1979). At age 15, a 15000 tree/ha planting density produced 7 percent of forked trees, whereas a 5900 tree/ha planting density produced 19 percent of forked trees. Competition for light has been studied by DUPRE (1984) in naturally regenerated seedling patches in beech stands. Full light increases height growth as compared with half shelter or full shelter by the canopy of remaining mature trees. Although no polycyclism had occurred in that particular case, full light also increased the forking risk. In another observation reported by LE TACON (1983), it has been suggested that full light also favours polycyclism and potentially forking when polycyclism results in malformation of the terminal bud. Our provenance tests throw some light on the influence of competition for nutrients on forking. The total height growth at age 11 (see § 3-1) suggests that the Chaud trial occupies a rather fertile site. Soil fertility probably does not vary much from one year to the next, but DUPRE (1984) has noticed severe changes in rainfall during the growing season (April to August) : $312 \mathrm{~mm}$ in 1982 and $618 \mathrm{~mm}$ in 1983 with similar average temperature $\left(14.1\right.$ and $14.6^{\circ} \mathrm{C}$ respectively). This rainfall difference seems to have resulted in a difference in the frequency of polycyclism : 52 percent in 1982 and 81 percent in 1983. Such a dependency of polycyclism, and therefore forking risk, on site conditions had already been mentioned by Galoux (1966). He concluded that a fairly strong genetic control of these characteristics exists (the total genetic variance explains 75 percent of the variation) but also that a strong genotype-site interaction partly hides the variability.

\subsection{Correlation between characteristics}

It has already been mentioned that budding and height growth are two independant traits. This is also the case for height growth and forking in all trials, and for stem diameter and forking in all trials except Chaud. In the latter the correlation is positive. It means that, the thicker the trees are the larger the number of forks they produce. So the relationship between vigour and forking is either neutral or unfavourable. It has not been explained as yet.

\subsection{How to choose the best provenances}

Because of strong provenance-site interaction for vigour and forking, practical use of our results is awkward. Choosing the best provenances for each reafforestation site supposes the existence of provenance trials in the neighbourhood. Our multisite provenance trials do not cover all the reafforestation areas and do not include all the potential seed stands. It has therefore been suggested to the National Forest Office to establish such a series of trials, and, when impossible, to rely on local provenances or on provenances originating from regions with similar ecological conditions.

In our set of trials it is difficult to find provenances which surely exibit both the 
best growth and a limited amount of forks. Careful observation will enable certain choices. In Orléans 11, eight provenances (Chatillon, Arguenos, Perche-Trappe, Souilly, Halatte, Brotonne, Retz and Compiègne) are above average for both height and form. Similarly, two such provenances exist in Ecouves (Retz and Sousceyrac), and three in Chaud (Aubrac, Hesdin and Compiègne). For low elevation unsheltered sites with spring frost risks, Chatillon, Compiègne, Sousceyrac and Perche-Trappe would probably be a good compromise, provided no other limiting factors exist (for instance soil $\mathrm{pH}$ ). Such compromises have already been mentioned by other authors like KLEINSCHMIT in Lower Saxony (1977).

\section{Conclusion}

Beech is widely spread in France and it covers an large range of sites. Plantation takes place when natural regeneration is impossible or incomplete. Beech may also be considered as a potential afforestation species on alcaline soils in pure or mixed stands. Unfortunately, many 20 to 30 year-old planted stands which needed a first thinning showed an insufficiant number of trees without forks. Among the factors which influence form and forking, genetic factors and site factors have been particularly studied both in the present paper and in others which have been mentioned in the text. Despite a certain genetic control of forking, but because of a strong genotype-site interaction, most efforts to improve tree form will have to rely on a limited number of favourable provenances and on silvicultural measures like high planting density and/or shelter.

\section{Acknowledgement}

We wish to thank $P^{r}$ Roelof Oldeman, $D^{r}$ Jochen Kleinschmidt and $D^{r}$ Pierre Bouvarei. for their efficient help in reviewing this paper. We ave very grateful to Herve Duval for his technical assistance in maintaining and measuring the experiments and to Patricia MONTES for her kindness and patience in typing this paper.

Reçu le 24 novembre 1987.

Accepté le 12 avril 1988.

\section{References}

Azoevf P., Hoslin R., Kieinschmit J., Teissier du Cros E., 1980. Spiral grain in beech, variability and heredity. Silvae Genetica, $29(1), 5-13$, also published in German in Forstarchiv, 51 (3), 41-47.

Barrière G., Comps G., Cuguen J., N'Tsiba F., Thiebaut B., 1985. The general ecological variability of beech (Fagus sylvatica L.) in Europe. An alloenzymatic study : genetic isolation 
of beechwoods. Proceedings of the Ist Symposium of I.U.F.R.O. Project Group Pl. 10-00. Improvement and Silviculture of Beech. June 1984. Grosshansdorf. F.R.G. Forst- und Holzwirtschaft, 24-50.

Cuguen J., Thiebaut B., N'Tsiba F., Barrière G., 1985. Enzymatic variability of beech stands (Fagus sylvatica L.) on three scales in Europe: evolutionary mechanism. NATO-ASI series, vol. G5. JACQUARD P. et al., Editors. Genetic differenciation and dispersal in plants. Springer Verlag. Berlin, Heidelberg, 17-24.

Dupre S., Teissier du Cros E., Thiebaut B., 1984. Morphologie et architecture des jeunes hêtres (Fagus sylvatica L.). Influence du milieu et variabilité génétique. Proceedings of the 1st Symposium of I.U.F.R.O. Project Group Pl. 10-00. Improvement and sylviculture of Beech. June 1984. Grosshansdorf. F.R.G. Forst- und Holzwirtschaft, 143-171.

Dupre S., 1984. Morphologie et architecture des jeunes plants de hêtre. Influence du milieu et de la variabilité génétique. Mémoire $3^{e}$. Ecole d'Ingénieur des Travaux des Eaux et Forêts. Montpellier. Orléans. $85+$ appendix.

Dupre S., Teissier du Cros E., Thiebaut B., 1985. Polycyclisme vigueur et forme chez de jeunes hêtres plantés (Fagus sylvatica L.). Revue Forest. Franç., 37 (6), 456-464.

Dupre S., Thiebaut B., Teissier du Cros E., 1986. Morphologie et architecture des jeunes hêtres (Fagus sylvatica L.). Influence du milieu, variabilité génétique. Ann. Sci. Forest., 43 (1), 85102 .

GaLoux A., 1966. La variabilité génécologique du hêtre commun (Fagus sylvatica L.) en Belgique. Groenendael-Hoeilaart : Station de recherches des Eaux et Forêts. Travaux série A, n ${ }^{\mathrm{l}} 11$, $121 \mathrm{p}$.

KLEINSCHMIT J., 1979. Forstpflanzenzüchtung und Saatgutbereitstellung beim Laubholz. Der Forstund Holzwirt, 32 (10), $7 \mathrm{p}$.

Lepoutre B., Teissier du Cros E., 1979. Croissance et nutrition de jeunes hêtres (Fagus sylvatica L.) de différentes provenances sur substratum naturel acide et sur même substratum calcarifié. Ann. Sci. Forest., 36 (3), 239-262.

LE TACON F., 1983. La plantation en plein découvert : une des causes de la mauvaise forme du hêtre dans le nord-est de la France. Revue Forest. Franç., 35 (6), 452-461.

Muhle O. and Kappich I., 1979. Erste Ergebnisse eines Buchen Provenienz- und Verbandsversuchs in Forstamts Bramwald. Forstarchiv, 50 (4), 65-69.

Teissier du Cros E., 1981. Amélioration génétique du hêtre. In : Le "Hêtre ", INRA, Paris, 445466.

Teissier du Cros E., Lepoutre B., 1983. Soil provenance interaction in Beech (Fagus sylvatica L.). Forest Science, 29 (2), 403-411.

Thiebaut B., 1984. Variabilité génétique écologique du hêtre commun (Fagus sylvatica L.) dans les milieux montagnards et de haute altitude en Europe. Document d'Ecologie Pyrénéenne, Vol. 3-4, 513-51.

Thiebaut B., Cuguen J., Dupre S., 1985. Architecture des jeunes hêtres. Fagus silvatica. Can. J. Bot., 63, 2 100-2 110. 